ship of the Council of Scientific and Industrial Research, India. We thank Dr. J. Chakraborty for suggesting the fixative, and Mr. J. C. Mondal for assistance.

S. K. SARKaR

R. K. PODDAR

Biophysics Division,

Saha Institute of Nuclear Physics, Calcutta 9, India.

${ }^{1}$ Schmidt, G., Sheraidarian, K., Greenbaum, L. M., Hickey, M. D., and Thannhauser, S. J., Biochim. Biophys. Acta, 20, 135 (1956).

${ }^{2}$ Halvorson, H., Biochim. Biophys. Acta, 27, 255 (1958).

${ }^{3}$ Halvorson, H., Biochim. Biophys. Acta, 27, 267 (1958).

'Swenson, P. A., J. Cell Comp. Physiol., 56, 77 (1960).

Thomas, E. D., Hershey, F. B., Abbate, A. M., and Loofbourow, J. R. J. Biol. Chem., 186, 575 (1952)

- Mahler, H. R., and Pereira, A. DA. S., J. Mol. Biol., 5, 325 (1962).

\section{Plaque-formation on the Chorioallantoic Membrane, by Isologous Spleen Cells, under the Influence of Homologous Bursa of Fabricius Cells}

THE thymus and the bursa of Fabricius are both essential for the development of immunological competence in birds. The bursa of Fabricius seems to be responsible for the development of the cells producing serum antibodies ${ }^{1}$ and delayed hypersensitivity reactions ${ }^{2}$, whereas the thymus is more particularly involved in homograft reactions ${ }^{3,4}$. The fact that the thymus shows evidence of at least partial activity when implanted in a 'Millipore' chamber impermeable to cells ${ }^{5}$ suggests that its influence is humoral.

If the bursa is instrumental in inducing cells to become immunologically competent it could extend this function either $(a)$ by creating conditions which enable inactive cells to start making antibody, according to their predetermined capacity, or $(b)$ by inducing responsive cells to produce antibody in answer to any antigenic stimulus.

To test this, we used the phenomenon of production of plaques (nodules) on the chorioallantoic membrane (CAM) of developing chick embryo by inoculation of a suspension of blood or spleen cells ${ }^{B, 7}$. When the recipient embryo and the donor of the blood or spleen cells belong to different strains, the intensity of the plaque reaction is determined by the genetic differences between the strains ${ }^{8}$.

We found that with highly inbred strains which are comparable with pure lines of mice, very fow plaques appear, whereas with crossbred strains the embryos show plaques in great numbers. Numerous plaques appeared at 95-98 per cent of the embryos when cells of a foreign strain such as Australorp $-(A)$, White-Rock or New-Hampshire were inoculated on the CAM of Leghorn Schatz Israel (LSI) embryos. In contrast to that when LSI embryos were inoculated with cells of an adult hen of the same inbred strain, only 2 per cent of the embryos reacted, with the appearance of occasional plaques ${ }^{\mathbf{8}, 10}$.

The experiments that we report here consist of the inoculation of a combination of isologous spleen cells of adult (6-8 month) hens ( $10^{4}$ cells per inoculation) with the same quantity of homologous bursa cells. This combination caused the appearance of plaques. Bursa and spleen cells alone were ineffective. The ability of the bursa cells to induce plaque formation was dependent on the age of the bursa donor.

Inoculations on the CAM were performed on the 9 th day of incubation and the results were examined after another 5 days. Of 112 LSI embryos inoculated with bursa cells ( $2 \times 10^{4}$ cells per inoculation) of $A$-chicken (5-16 weeks) none showed the appearance of plaques. Only 5 out of 103 LSI embryos inoculated with LSI spleen cells $\left(2 \times 10^{4}\right.$ cells per inoculation) showed plaques. In $66-54 \cdot 6$ per cent of the embryos inoculated with the combination of spleen and bursa cells of this age-group, plaques appeared in significantly great numbers in contrast to inoculations with spleen and bursa cells alone. When the bursa donor

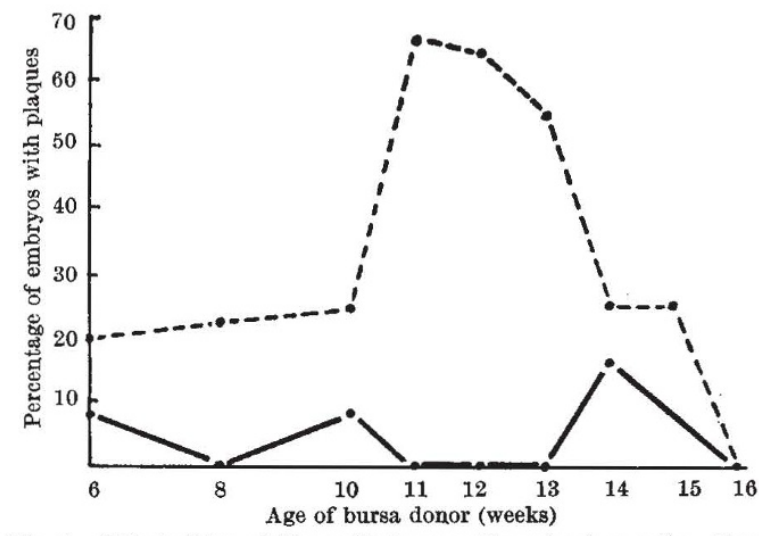

Fig. 1. Effect of inoculation with bursa cells and spleen cells. Bursa cells alone caused no formation of plaques. Spleen cells alone;

was younger or older, the number of positive results diminished, as seen in Table 1 and Fig. 1. Maximum reactivity of the bursa cells was observed at the age of 11-13 weeks. Table 1. APPEARANCE of PLAQUES ON THE CAM OF LSI EMBRYOS INOCDAATED ON THE 9TH DAY, 5 DAYS AFTER INOCULATION WITH SP

$\begin{array}{ccc}\begin{array}{c}\text { Age of } \\ \text { bursa donor } \\ \text { (weeks) }\end{array} & \begin{array}{c}A \text { bursa } \\ \text { cells alone }\end{array} & \text { LSI spleen cells } \\ \text { alone } & \text { A bursa cells }+ \\ \text { LSI spleen cells }\end{array}$

(weeks)

$\begin{array}{rllrll} & & & & \\ 6 & 0 / 9 & 1 / 11 & \% & 2 / 10 & 20 \\ 8 & 0 / 10 & 0 / 10 & 0 & 3 / 13 & 23 \\ 10 & 0 / 16 & 1 / 13 & 8 & 2 / 8 & 25 \\ 11 & 0 / 12 & 0 / 8 & 0 & 6 / 9 & 66 \\ 12 & 0 / 14 & 0 / 8 & 0 & 9 / 14 & 64 \\ 13 & 0 / 12 & 0 / 13 & 0 & 6 / 11 & 54 \cdot 6 \\ 14 & 0 / 12 & 2 / 12 & 16 & 3 / 12 & 25 \\ 15 & 0 / 13 & 1 / 11 & 8 & 3 / 13 & 25 \\ 16 & 0 / 14 & 0 / 17 & 0 & 0 / 14 & 0\end{array}$
Number of cells inoculated was $2 \times 10^{4}$ per inoculation; numerator $=$ the
number of embryos with plaques; denominator $=$ total number of embryos number of embryos with plaques; denominator $=$ total
inoculated; $\%=$ percentage of positive results obtained.

These experiments confirm the fact that isologous spleen cells are unable to react in the CAM of their own strain. The small number of plaques in a low percentage of embryos could be explained through some residual antigenic heterogeneity of the 'pure' strain, possibly because of sex differences, although we tried to use only hens and no cocks as donors.

The results of the experiments show that isogenic cells cannot react against their own antigens present in the embryo; in the terminology of Burnet ${ }^{11}$, these spleen cells are tolerant to isologous cells, but are induced to recognize the same antigen as foreign when under the influence of homologous (allogenic) bursa cells.

Addendum. Attempts to reproduce the results with other strain combinations were not fully successful. The strain Leghorn Schatz has now lost its purity through cross-breoding.

We thank Mr. J. Shlomo and Mrs. N. Raz for their help. This work was supported by a grant from the National Council for Research and Development, Israel. A. KLopstock

Department of Microbiology,

R. Sharon

University of Tel-Aviv, Israel.

1 Muller, A. P., Wolfe, H. R., and Mayer, R. K., J. Immunol., 188, 354 (1962)

"Warner, N. L., Szenberg, A., in Die Biologie des Thymus, 57, edit, by Miller, J. F. A. P. and Dukor, P. (Basle, 1964).

${ }^{3}$ Aspinal, R. I., Mayor, R. K., Braetzer, A., and Wolfe, H. R., J. Immunol., 80, $872(1963)$.

Warner, N. L., and Szenberg, A., Nature, 199, 43 (1963).

${ }^{6}$ Osoba, D., and Miller, J. F. A. P., Nature, 199, 653 (1963).

- Boyer, G. S., Nature, 185, 327 (1960).

? Burnet, F. M., and Boyer, G. S., J. Path. Bact, 81, 141 (1961).

s Burnet, F. M., Science, 133, 3449 (1961).

- Klopstock, A., Schwartz, J., and Sharon, R., Refuah Veterinarith, 18, 249 (1962).

${ }^{10}$ Schwartz, J., Klopstock, A., and Sharon, R., Giornale di Microbiol., 10, 197 (1962).

11 Burnet, F. M., The Clonal Selection Theory of Acquired Immunity, 4 (Yanderbilt University Press, 1955). 